Research Article

\title{
Sustainable Reuse of Dredged Soil as a Substrate Material by Improvement with Polyacrylamide, Straw, and Superabsorbent Polymer
}

\author{
Ling Mei $\mathbb{i}$, Yuxiang Chen, and Lei Wang \\ College of Civil Engineering and Architecture, Jiangsu University of Science and Technology, Zhenjiang 212000, China \\ Correspondence should be addressed to Ling Mei; mling530@163.com
}

Received 12 October 2020; Revised 18 March 2021; Accepted 16 September 2021; Published 30 September 2021

Academic Editor: Pengfei Liu

Copyright (c) 2021 Ling Mei et al. This is an open access article distributed under the Creative Commons Attribution License, which permits unrestricted use, distribution, and reproduction in any medium, provided the original work is properly cited.

\begin{abstract}
Every year, a significant quantity of dredged soil is generated as a result of channel dredging operations. However, there is relatively little evidence available regarding the sustainable reuse of dredged soils. In this study, an improved substrate material mainly composed of dredged soil was developed to examine the effects of three substrate amendments on the soil's nutritional content, physical properties, and water retention capacity, as well as the germination rate of tall fescue. The orthogonal combination of the three substrates was controlled in a pot experiment using polyacrylamide (PAM), rice straw, and superabsorbent polymer (SAP) at application rates of $0.5,1,1.5,2$, and $2.5 \mathrm{~g} / \mathrm{kg} ; 15,20,25,30$, and $35 \mathrm{~g} / \mathrm{kg}$; and $0,3,6,9$, and $12 \mathrm{~g} / \mathrm{kg}$, respectively. The results showed that adequate application of PAM may improve the water retention capacity and available $\mathrm{N}$ retention capacity of dredged soil. PAM inhibited tall fescue germination significantly when the concentration exceeded $0.5 \mathrm{~g} / \mathrm{kg}$ $(p<0.05)$. The addition of rice straw significantly improved the nutritional content of dredging soil and the germination rate of tall fescue $(p<0.05)$. Increased SAP significantly decreased the bulk density of dredged soil $(p<0.05)$. The lowest test group was $48.20 \%$ less than CK. This study offers novel ideas for the sustainable reuse of dredged soil and serves as a guide for future research aimed at increasing the effectiveness of external-soil spray seeding technologies.
\end{abstract}

\section{Introduction}

Dredged soil is a sediment mixture of loose particles consisting of clay, silt, and sand generated by the erosion and weathering of soils, rocks, and organic materials, as well as human activity [1]. Sediment deposition in various water sources causes transportation and shipping problems due to river shoaling. These dredged soils, which are considered waste materials, are deposited in the sea or on land. By 2015, for example, more than 14 billion $\mathrm{m}^{3}$ of dredged soils had been dredged yearly from China's major rivers and commercial ports [2]. Dredged soils are often classified as waste materials and dumped in the ocean or a storage yard $[3,4]$, although these materials should ideally be reused.

Several studies have focused on the reuse of dredged soils as pavement materials, such as subgrade, selected material subbase, and base courses $[5,6]$. However, the majority of dredged soils are fine-grained materials, such as silts and clays, with a high void ratio, high compressibility, poor strength, low bearing capacity, and the presence of organic matter [1]. Improving dredged soil as a substrate material has the potential to successfully transform it into a valuable soil resource. Substrate material, a novel product with improved water conservation, thermal insulation, low cost, and ease of maintenance, has been studied as a promising slope material [7-9].

It is critical to screen for and identify suitable amendments that may be used to enhance dredged soils to satisfy engineering requirements. The soil may be amended with substances such as anionic polyacrylamide (PAM), which often produces significant levels of physical impacts from a relatively little quantity of material [10-12]. Numerous forms of anionic PAM are produced as soil conditioners for agricultural applications in several locations globally, 
including to control infiltration, runoff, and soil erosion, as well as to decrease nutrient loss from the soil due to irrigation $[13,14]$. Recent research on the use of anionic PAM to improve dredged sediments has mostly focused on using it with powder concrete to enhance the strength and reduce the water content of dredged sediments [15-17]. However, little research has been conducted on the effects of PAM on vegetation growth and nutrient retention in dredged soil. In addition, although much research has been conducted on the effectiveness of PAM, there is a dearth of quantitative information detailing the synergistic effects of PAM and other amendments, such as straw and other water retention agents, on dredged soil.

For well over a century, residents in many small towns in China and Korea have combined rice straw with mud to construct village walls [18]. Rice straw is now extensively utilized in agriculture and the environment. Straw is emerging as a solution in agriculture and the environment for enhancing crop growth, increasing soil aggregate, and increasing soil organic carbon $[19,20]$. Some studies have found that, in the natural environment, microorganisms degrade rice straw to generate $\mathrm{N}$ and $\mathrm{CO}_{2}$. These compounds react with magnesium sulfate in rice straw to generate $\mathrm{MgCO}_{3}$ and $\left(\mathrm{NH}_{4}\right)_{2} \mathrm{SO}_{4}$, which are nutrients required by plants, lowering the $\mathrm{pH}$ of rice straw compost [21,22]. As a result, we selected rice straw in this study to explore its synergetic effect with other substrates to improve the nutritional content and reduce the $\mathrm{pH}$ value of dredged soils.

Finally, a common water absorbent with excellent water absorption, superabsorbent polymer (SAP), has been used in the agricultural sector as a water-saving agent [23]. It has been shown that incorporating a superabsorbent polymer into soil improves its physical properties, resulting in enhanced infiltration and decreased evaporation and soil erosion during irrigation $[24,25]$. When polymers are mixed into soil, it is assumed that they retain large amounts of water and nutrients that can be absorbed by plant roots and enhance seed germination and emergence, as well as crop growth and yield [26-28]. Therefore, SAP may be utilized in agricultural and environmental protection as an efficient water and fertilizer retention agent. In summary, PAM, rice straw, and SAP are typical dredging soil conditioners, making them a suitable and practical option for this study.

The objectives of this study were to (1) investigate the effects of different application rates of various substrate amendments (PAM, SAP, and rice straw) on the nutrient contents (soil organic matter; extractable N, P, and K) of dredged soil, (2) investigate the effects of different substrate amendments on the water retention and physical properties of dredged soil, and (3) assess the effects of various substrate amendments on the emergence rate of tall fescue in dredged soils.

\section{Materials and Methods}

2.1. Materials. Dredged soil was obtained from the dumping area of Xiaoxing Village $\left(32^{\circ} 4^{\prime} 49^{\prime \prime} \mathrm{N}, 119^{\circ} 34^{\prime} 34 \mathrm{E}\right)$, Zhenjiang, China, near the Beijing-Hangzhou Grand Canal. The substrate materials were as follows: (1) anionic PAM, provided by Xingbang Environmental Protection Technology Co., Ltd., Yiwu, China, with a high molecular weight of 8 million and a hydrolysis degree of $23.5 \%$; (2) rice straw smashed into $1-2 \mathrm{~cm}$ pieces; and (3) superabsorbent polymer (SAP), provided by Chengqi Chemical Engineering and Technology Co., Ltd., Shanghai, China, which consisted of a suspension-polymerized and covalently cross-linked acrylamide/acrylic acid copolymer. Table 1 shows the basic properties of the selected substrate materials and soil.

2.2. Experimental Design. Pot experiments were carried out at Jiangsu University of Science and Technology in Zhenjiang $\left(32^{\circ} 6^{\prime} 42^{\prime \prime} \mathrm{N}, 119^{\circ} 21^{\prime} 8 \mathrm{E}\right)$, Jiangsu Province, China, from May to August 2020. The mean annual temperature at this site was $15.4^{\circ} \mathrm{C}$, the mean annual precipitation was $817 \mathrm{~mm}$, and the mean annual evaporation was $\sim 1423 \mathrm{~mm}$. The pots $(12 \mathrm{~cm}$ deep, $16 \mathrm{~cm}$ top diameter, and $13 \mathrm{~cm}$ bottom diameter) were washed with tap water before the experiment.

An orthogonal design method was used to optimize the formulation of the substrate material as well as to evaluate the material properties and the degree of impact of various factors. According to previous reports on the water and fertilizer conservation of the aforementioned substrates $[8,14,29]$, the dosage gradient of PAM in the soil was determined to be A1 $(0.5 \mathrm{~g} / \mathrm{kg}), \mathrm{A} 2(1 \mathrm{~g} / \mathrm{kg}), \mathrm{A} 3(1.5 \mathrm{~g} / \mathrm{kg}), \mathrm{A} 4$ $(2 \mathrm{~g} / \mathrm{kg})$, and $\mathrm{A} 5(2.5 \mathrm{~g} / \mathrm{kg})$; straw was controlled to B1 $(15 \mathrm{~g} /$ $\mathrm{kg}), \mathrm{B} 2(20 \mathrm{~g} / \mathrm{kg}), \mathrm{B} 3(25 \mathrm{~g} / \mathrm{kg}), \mathrm{B} 4(30 \mathrm{~g} / \mathrm{kg})$, and B5 (35 g/ $\mathrm{kg})$; and SAP was C1 $(0 \mathrm{~g} / \mathrm{kg}), \mathrm{C} 2(3 \mathrm{~g} / \mathrm{kg}), \mathrm{C} 3(6 \mathrm{~g} / \mathrm{kg}), \mathrm{C} 4$ $(9 \mathrm{~g} / \mathrm{kg})$, and $\mathrm{C} 5(12 \mathrm{~g} / \mathrm{kg})$. According to the range of the variable, five levels were selected for each factor, thus the five-level table was chosen. The interaction of the variables was disregarded, and only four factors were selected. The appropriate table for the experiment was $L_{25}\left(5^{3}\right)$. In Table 2, the orthogonal experiment's factors and levels are listed.

There were 25 treatments, each with three parallel sets, and CK was used as the blank control group (Table 2). Each group received 78 pots of tall fescue seeds. Each pot was filled with $1000 \mathrm{~g}$ of dredged soil and a variety of substrate amendments in varying amounts.

Soil samples collected from the field were first naturally dried and sieved using a $2 \mathrm{~mm}$ sieve, before being put to the pot with mixed substrate materials. The container was then filled with $500 \mathrm{~g}$ of water and left to stand for $24 \mathrm{~h}$, before being watered again to soil saturation, and twenty seeds were implanted. Between May 2020 and June 2020, the seeds were cultured in nursery gardens (Figure 1). During this time, the seedlings were watered every two days and the saturated water content was maintained at $70 \%$.

2.3. Soil Sampling and Analysis. The core method $(5 \mathrm{~cm}$ height $\times 5.46 \mathrm{~cm}$ diameter) was used to estimate bulk density, total porosity, and saturated water capacity. The $\mathrm{H}_{2} \mathrm{SO}_{4}{ }^{-}$ $\mathrm{K}_{2} \mathrm{Cr}_{2} \mathrm{O}_{7}$ oxidation method was sued to measure soil organic C [30]. A $2 \mathrm{~mol} / \mathrm{L} \mathrm{KCl}$ solution was used to extract extractable $\mathrm{N}$. After $\mathrm{NH}^{4+}$ on soil colloid was replaced by $\mathrm{K}^{+}$, it reacted with hypochlorite and phenol in a strongly alkaline medium to form water-soluble dye indophenol blue. The color depth of the water-soluble dye indophenol blue was 
TABLE 1: The basic physical and chemical properties of the dredged soil and the selected substrates in the substrate material.

\begin{tabular}{|c|c|c|c|c|c|}
\hline Soil properties & Value & SAP properties & Value & PAM properties & Value \\
\hline $\mathrm{pH}$ & 8.7 & Particle size range $(\mathrm{mm})$ & $0.25-0.6$ & Type & Anionic \\
\hline Liquid limit (\%) & 39 & Water absorbency (g/g) & 600 & Color & White \\
\hline Plastic limit (\%) & 20 & Color & White & MW & $8 \times 10^{7}$ \\
\hline Extractable $\mathrm{N}(\mathrm{mg} / \mathrm{kg})$ & 44.24 & & & $\mathrm{DH}(\%)$ & 23.5 \\
\hline Extractable P (mg/kg) & 44.45 & & & Density $\left(\mathrm{g} / \mathrm{cm}^{3}\right)$ & 1.32 \\
\hline Extractable $\mathrm{K}(\mathrm{mg} / \mathrm{kg})$ & 175.5 & & & $\mathrm{GT}\left({ }^{\circ} \mathrm{C}\right)$ & 188 \\
\hline Organic C (g/kg) & 2.4 & & & $\mathrm{ST}\left({ }^{\circ} \mathrm{C}\right)$ & 210 \\
\hline Sand $(\%)$ & 87.7 & & & & \\
\hline Silt (\%) & 6.18 & & & & \\
\hline Clay (\%) & 3.68 & & & & \\
\hline
\end{tabular}

MW, molecular weight; DH, degree of hydrolysis; GT, glass temperature; ST, softening temperature.

TABLE 2: The orthogonal combination of the three substrates in pot experiments.

\begin{tabular}{|c|c|c|c|}
\hline Treatment & Factor A: PAM $(\mathrm{g} / \mathrm{kg})$ & Factor B: straw $(\mathrm{g} / \mathrm{kg})$ & Factor C: SAP $(\mathrm{g} / \mathrm{kg})$ \\
\hline 1 & A1 (adding 0.5) & B1 (adding 15) & C1 (no adding) \\
\hline 2 & A2 (adding 1) & B1 (adding 15) & C2 (adding 3) \\
\hline 3 & A3 (adding 1.5) & B1 (adding 15) & C3 (adding 6) \\
\hline 4 & A4 (adding 2) & B1 (adding 15) & C4 (adding 9) \\
\hline 5 & A5 (adding 2.5) & B1 (adding 15) & C5 (adding12) \\
\hline 6 & A4 (adding 2) & B2 (adding 20) & C5 (adding12) \\
\hline 7 & A3 (adding 1.5) & B2 (adding 20) & C4 (adding 9) \\
\hline 8 & A2 (adding 1) & B2 (adding 20) & C3 (adding 6) \\
\hline 9 & A1 (adding 0.5) & B2 (adding 20) & C2 (adding 3) \\
\hline 10 & A5 (adding 2.5) & B2 (adding 20) & C1 (no adding) \\
\hline 11 & A4 (adding 2) & B3 (adding 25) & C1 (no adding) \\
\hline 12 & A3 (adding 1.5) & B3 (adding 25) & C2 (adding 3) \\
\hline 13 & A5 (adding 2.5) & B3 (adding 25) & C3 (adding 6) \\
\hline 14 & A1 (adding 0.5) & B3 (adding 25) & C4 (adding 9) \\
\hline 15 & A2 (adding 1) & B3 (adding 25) & C5 (adding12) \\
\hline 16 & A1 (adding 0.5) & B4 (adding 30) & C5 (adding12) \\
\hline 17 & A2 (adding 1) & B4 (adding 30) & C4 (adding 9) \\
\hline 18 & A4 (adding 2) & B4 (adding 30) & C3 (adding 6) \\
\hline 19 & A5 (adding 2.5) & B4 (adding 30) & C2 (adding 3) \\
\hline 20 & A3 (adding 1.5) & B4 (adding 30) & $\mathrm{C} 1$ (no adding) \\
\hline 21 & A2 (adding 1) & B5 (adding 35) & C1 (no adding) \\
\hline 22 & A4 (adding 2) & B5 (adding 35) & C2 (adding 3) \\
\hline 23 & A1 (adding 0.5) & B5 (adding 35) & C3 (adding 6) \\
\hline 24 & A5 (adding 2.5) & B5 (adding 35) & C4 (adding 9) \\
\hline 25 & A3 (adding 1.5) & B5 (adding 35) & C5 (adding 12) \\
\hline $\mathrm{CK}$ & No adding & No adding & No adding \\
\hline
\end{tabular}
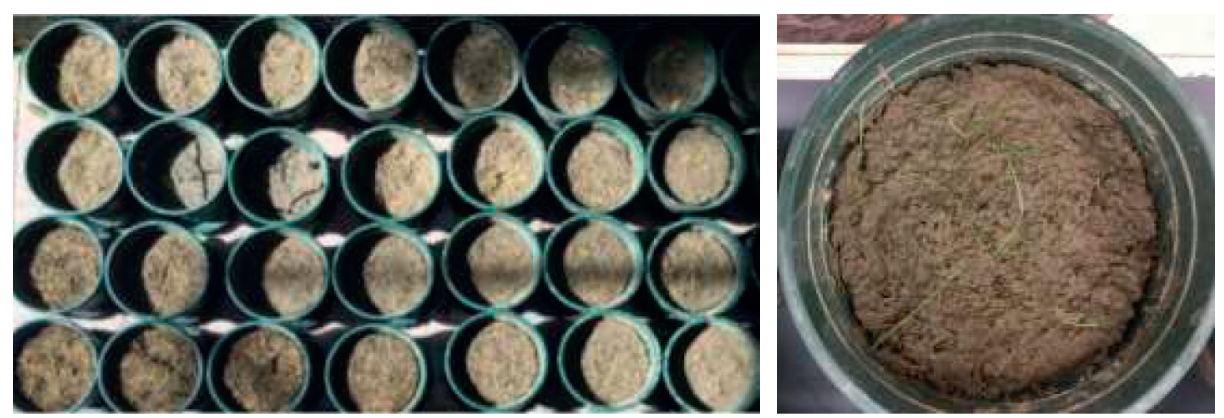

Figure 1: Tall fescue planted on substrate material at Jiangsu University of Science and Technology, Zhenjiang, Jiangsu Province, China.

proportional to the $\mathrm{N}$ content. $\mathrm{NaHCO}_{3}$ was sued to extract extractable P [31]. Extractable $\mathrm{K}$ was measured by atomic absorption spectrometry after extraction with a $1 \mathrm{~mol} / \mathrm{L}$
$\mathrm{NH}_{4} \mathrm{OAc}(\mathrm{pH}$ 7.0) solution [32]. The number of seedlings was recorded daily, and the tall fescue emergence rate was estimated based on the number of seedlings on the 28th day. 
For each soil sample, three replicate determinations were performed for each soil property.

2.4. Statistical Analyses. Data were analysed using one-way analysis of variance (ANOVA) in IBM SPSS 20 software, and the primary and secondary factors, as well as the best combination of them, were determined using range analysis. Origin 8.0 was used to conduct statistical mapping.

\section{Pot Experiment Results}

3.1. Soil Nutrient Contents. Organic C, extractable N, extractable $\mathrm{P}$, and extractable $\mathrm{K}$ are significant components of soil nutrient contents. Figure 2 indicates that all treatments with different amendments increased the organic $\mathrm{C}$, extractable $\mathrm{N}$, extractable $\mathrm{P}$, and extractable $\mathrm{K}$ content in dredged soil, although the magnitude of the increase varied across treatments. Figure 2(a) indicates that all treatments with various substrates increased organic $C$ when compared to the CK group, indicating that the combination of the three substrates may aid in increasing organic $\mathrm{C}$ in dredged soil. Treatment No. 23 performed the best of all substrate materials, increasing organic $\mathrm{C}$ by about $7.86 \mathrm{~g} / \mathrm{kg}$, accounting for $234.47 \%$ of the CK group. Treatment No. 23 fared the poorest in the dredged soil, increasing the organic $\mathrm{C}$ content by $4.50 \mathrm{mg} / \mathrm{kg}$, a $70.51 \%$ increase compared with the CK group. This resulted in a significant increase in the organic $\mathrm{C}$ content of dredged soil when varied substrate combinations were used. As shown in Figure 2(b), all treatments with various substrates improved the extractable $\mathrm{N}$ content of the substrate material when compared to the CK group. Among all treatments, treatment No. 19 produced the greatest $\mathrm{N}$ content in amended dredged soil, measuring $123 \mathrm{mg} / \mathrm{kg}$, which was $217.58 \%$ more than that of CK. Additionally, treatment No. 8 had the least improvement in terms of $\mathrm{N}$ content in dredged soil, at $66.04 \mathrm{mg} / \mathrm{kg}$, a $6.35 \%$ increase over the CK group. The extractable $\mathrm{P}$ content of various substrates in modified dredged soil is shown in Figure 2(c). Treatment No. 10 had the highest performance of all substrate materials, increasing extractable $\mathrm{P}$ by about $197.27 \mathrm{mg} / \mathrm{kg}$, which accounted for $234.47 \%$ of the CK group. In dredged soil, treatment No. 18 fared the poorest with an increase in extractable $\mathrm{P}$ of $59.7 \mathrm{mg} / \mathrm{kg}$, a $6.35 \%$ increase compared to the CK group. Figure 2(d) shows the variations in extractable $\mathrm{K}$ concentrations of different substrates in amended dredged soil. Treatment No. 16, at $1032.52 \mathrm{mg} / \mathrm{kg}$, performed the best across all substrate materials, increasing extractable $\mathrm{P}$ by $468.13 \%$, while treatment No. 21, at $244.83 \mathrm{mg} / \mathrm{kg}$, performed the worst, increasing extractable $\mathrm{P}$ by $38.98 \%$ compared with the $\mathrm{CK}$ group.

3.2. Physical Properties and Soil Water Retention Capacity. Figures 3 and 4 show the soil bulk density, total porosity, and saturated water capacity after different treatments, indicating that all substrate composite treatments affected the physical properties and soil water retention. Besides, this also indicated that the combination of the three substrates could help to improve the physical properties and water retention of the dredged soil. Figure 3 shows that compared to the CK group, all treatments with different substrates reduced the bulk density. Treatment No. 5 obtained the lowest soil bulk density of $0.72 \mathrm{~g} / \mathrm{cm}^{3}$ in dredged soil, which was $48.20 \%$ lower than that of CK. Furthermore, treatment No. 8 demonstrated the least degree of improvement for bulk density in dredged soil of $1.23 \mathrm{~g} / \mathrm{cm} 3$, with an $11.51 \%$ decrease when compared to the CK group. Figure 3 indicates that except for the No. 1, No. 9, and No. 20 treatments, the overall porosity of each substrate material was significantly improved as compared to the CK group. Treatment No. 5 performed the best of all substrate materials, increasing overall porosity by about $66.89 \%$, accounting for $29.73 \%$ of the CK group. Figure 4 shows that all treatments with different substrates improved the saturated water capacity and field capacity of substrate material when compared to the CK group, indicating that combining the three substrates may help to boost the soil water retention capacity for substrate material. Treatment No. 5 performed the best among all substrate materials, increasing saturated water capacity and field capacity by $118.97 \%$ and $124.50 \%$, respectively, as compared with the CK group.

3.3. Germination Rate of Tall Fescue. Figure 5 shows the emergence rate of tall fescue with different treatments, indicating that all substrate composite treatments improved the germination rate and that combining the three substrates may help to improve the germination rate of tall fescue in the dredged soil. Treatment No. 23 outperformed all other substrate materials, increasing the germination rate of tall fescue in the dredged soil by $400 \%$ as compared with the CK group.

\section{Analysis of the Orthogonal Experiment}

4.1. Range Analysis. The extractable P of the No. 23 experiment, for example, is maximum as shown in the experiment results in Figure 1. However, each treatment had a different impact on different indicators. A thorough study should be conducted to determine the optimal level combination and its influence on different indicators. As shown in Table 3, the average value of the experimental result at each level is denoted as $k 1, k 2, k 3, k 4$, and $k 5$. The theoretically optimal combination is that the average value of the experimental outcome is maximum. The range is defined as the difference between the maximum and minimum of the target's average, and it is denoted as $R$. The value of $R$ reflects the extent of the variable's influence on the target. The trend curve for each factor is given in Figure S1.

Table 3 shows the degree of influence of substrate material with three different substrates on the different indicators. The order of the degree of influence of each factor on the organic $\mathrm{C}$ and extractable $\mathrm{P}$ content was straw $>$ SAP $>$ PAM. The optimal combination of the three substrates for organic $\mathrm{C}$ was $\mathrm{A} 2 \mathrm{~B} 5 \mathrm{C} 5$, whereas the best combination for extractable $\mathrm{P}$ was A1B3C1. Furthermore, Table 3 shows that the order of the degree of influence of 


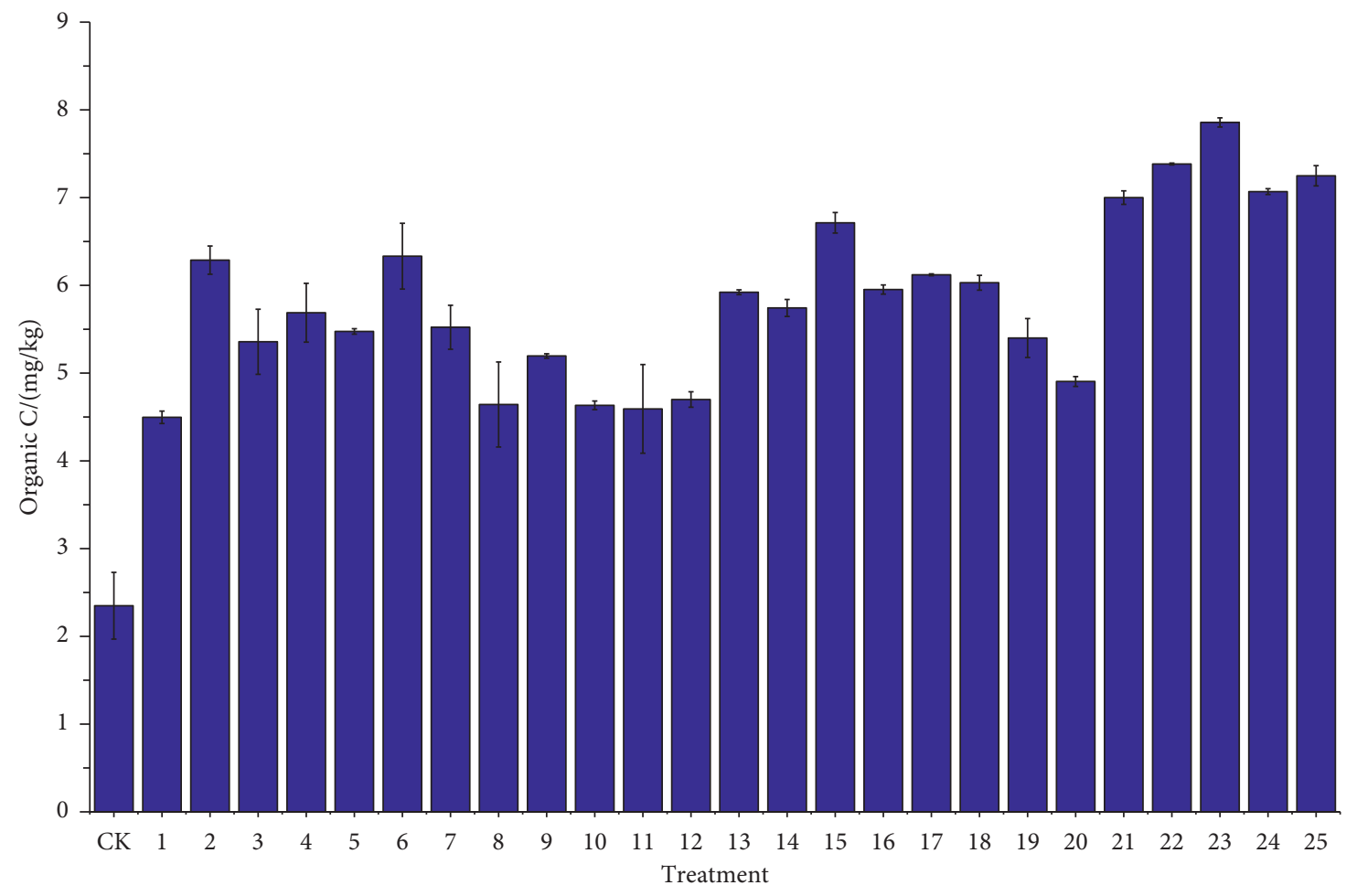

(a)

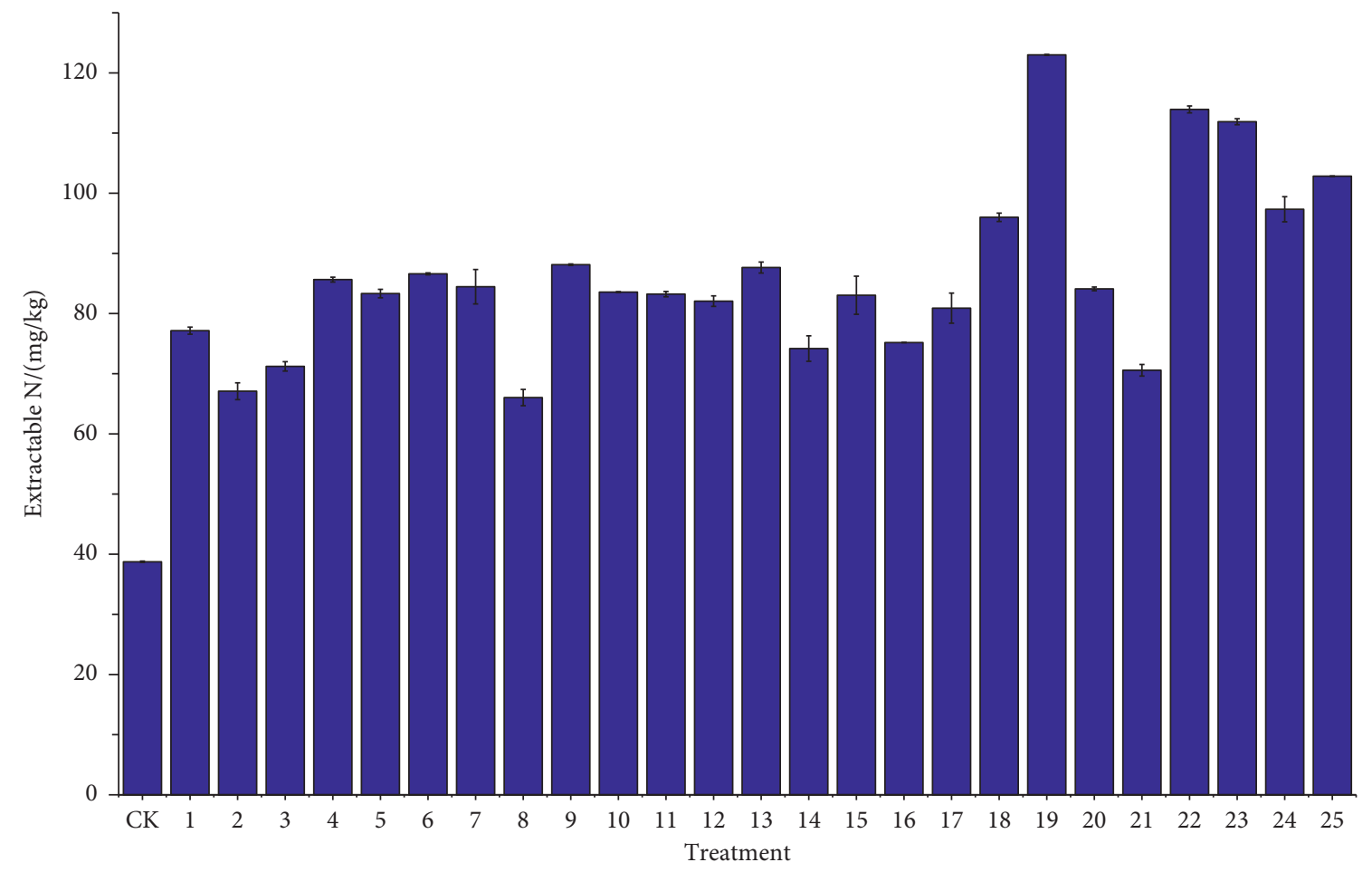

(b)

Figure 2: Continued. 


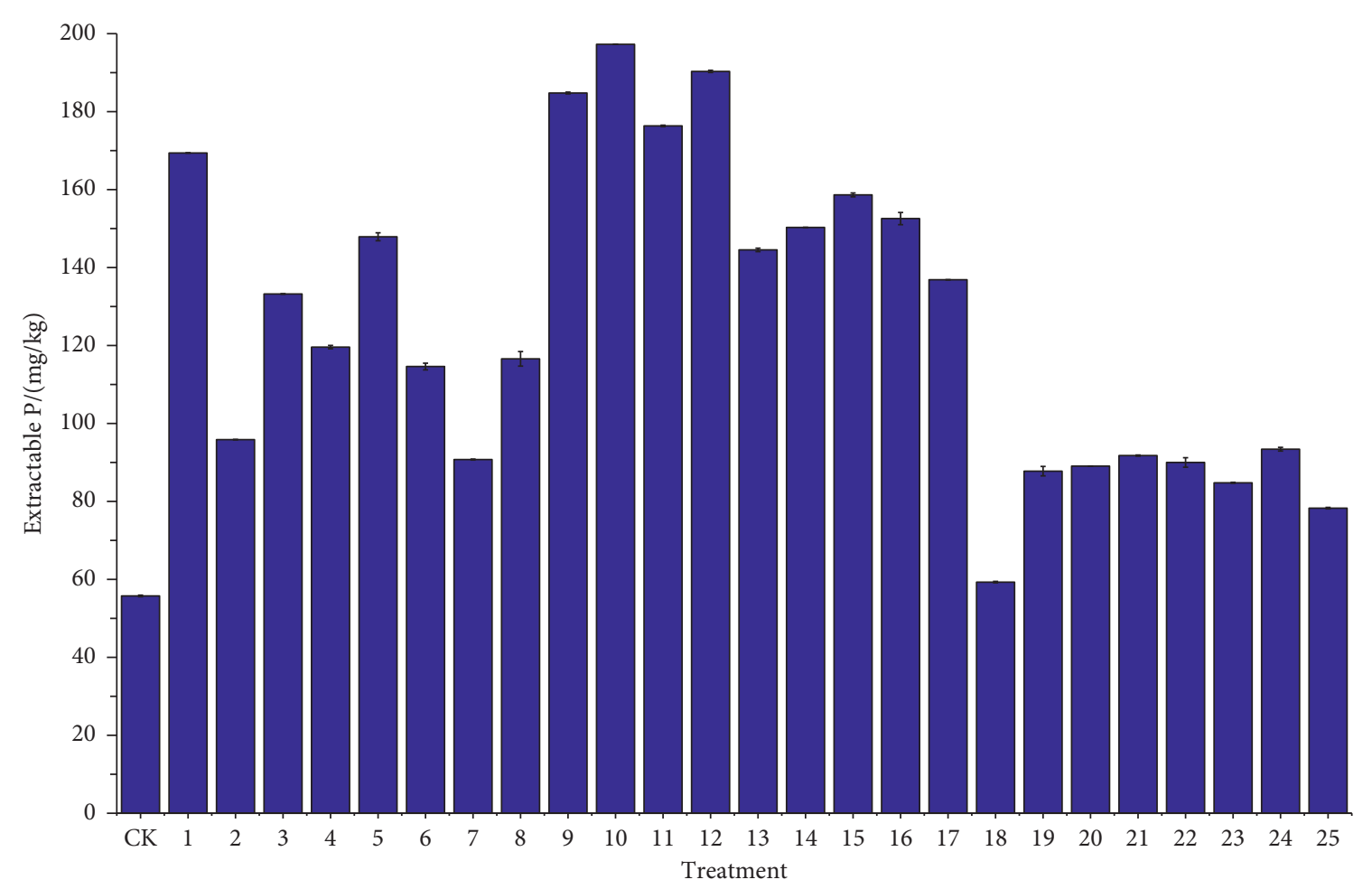

(c)

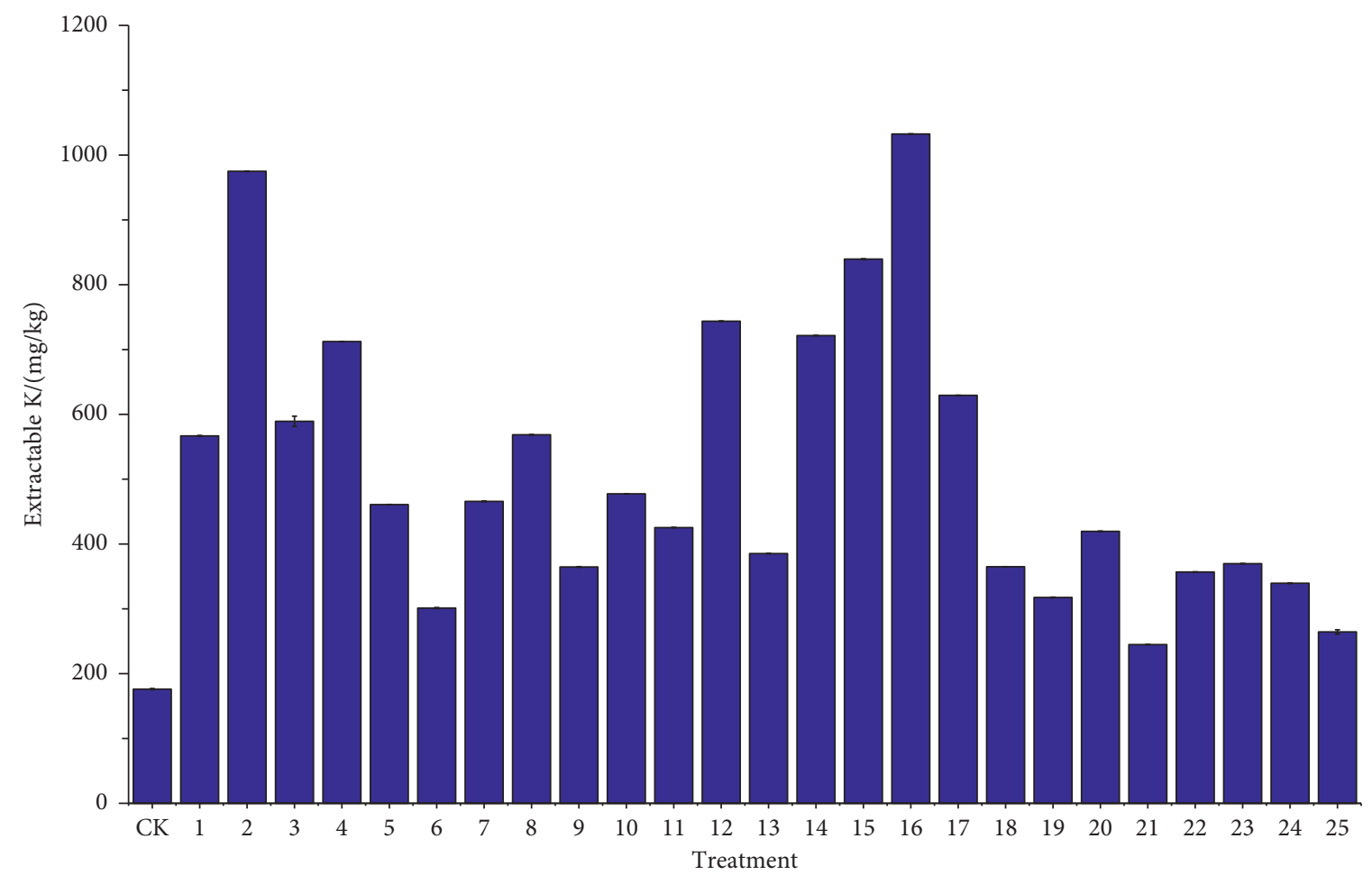

(d)

Figure 2: The organic $\mathrm{C}$ and available N, P, and $\mathrm{K}$ contents in different substrates. CK, control treatment. Nos. 1-25 indicate different substrate application levels. 


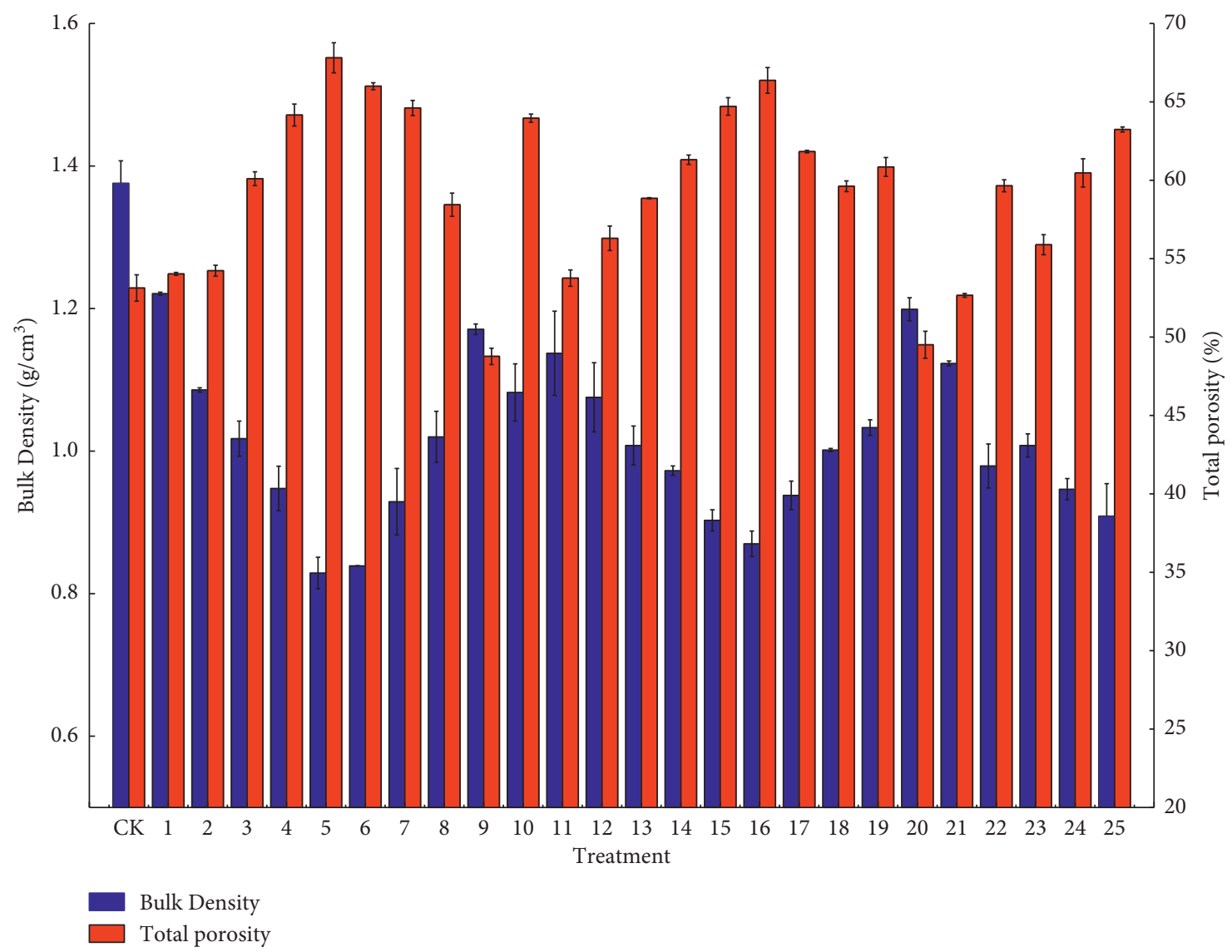

Figure 3: The bulk density and total porosity of different substrates.

each factor on the extractable $\mathrm{N}$ and $\mathrm{K}$ content was straw $>$ PAM $>$ SAP, while A5B5C2 and A2B1C5 were the best combinations of the three substrates for extractable $\mathrm{N}$ and extractable $\mathrm{K}$, respectively.

The order of each factor's impact on bulk density, total porosity, and saturated water capacity was SAP $>$ PAM > straw. The optimal combination of the three substrates for bulk density was A5B5C5, whereas the best combination for total porosity and saturated water capacity was A5B4C5.

According to the range analysis (Table 3), the order of the influence degree of each factor was PAM $>$ straw $>$ SAP. A1B5C2 was the optimal combination of the three substrates for increasing the germination rate of tall fescue in the dredged soil.

4.2. Variance Analysis. Range analysis shows the order of the variance influencing the target by intuition. However, it could not distinguish between undulation caused by different variable levels and undulation caused by experimental errors. It also does not offer a standard criterion for determining whether a variable's effect is discernible. The variance analysis is required to address the issue.

The results of the principal effect analysis with one-way analysis of variance (Table 4 ) indicate that the significance level of the substrate material with three different substrates on organic $\mathrm{C}$, extractable $\mathrm{N}$, extractable $\mathrm{P}$, extractable $\mathrm{K}$, bulk density, total porosity, saturated water capacity, and germination rate was different. Table 4 shows that straw and SAP content in the substrate material had a significant effect on organic C content $(p<0.05)$, while PAM content did not affect organic $\mathrm{C}$ content $(p>0.05)$. The extractable $\mathrm{N}$ content was significantly affected by straw and PAM content $(p<0.05)$, but not by SAP content $(p>0.05)$. Extractable $\mathrm{P}$ content was significantly affected by straw in the substrate material $(p<0.05)$, while PAM or SAP content did not affect available $\mathrm{P}$ content $(p>0.05)$. Straw had a significant effect on extractable $\mathrm{K}$ content $(p<0.05)$, while PAM and SAP content had little effect $(p>0.05)$.

Furthermore, Table 4 shows that SAP content in the substrate material had a significant effect on soil bulk density, total porosity, and saturated water capacity $(p<0.05)$, while PAM content did not affect soil bulk density, total porosity, saturated water capacity, or field capacity $(p>0.05)$. Variance analysis (Table 4) further showed that the germination rate of tall fescue in dredged soil was significantly affected by PAM, SAP, and straw content in the substrate material $(p<0.05)$.

\section{Discussion}

5.1. Effects of Different Substrates on Nutrient Contents. The results of this study show that rice straw had a significant effect on nutrient contents (organic $\mathrm{C}$ and extractable $\mathrm{N}, \mathrm{P}$, 


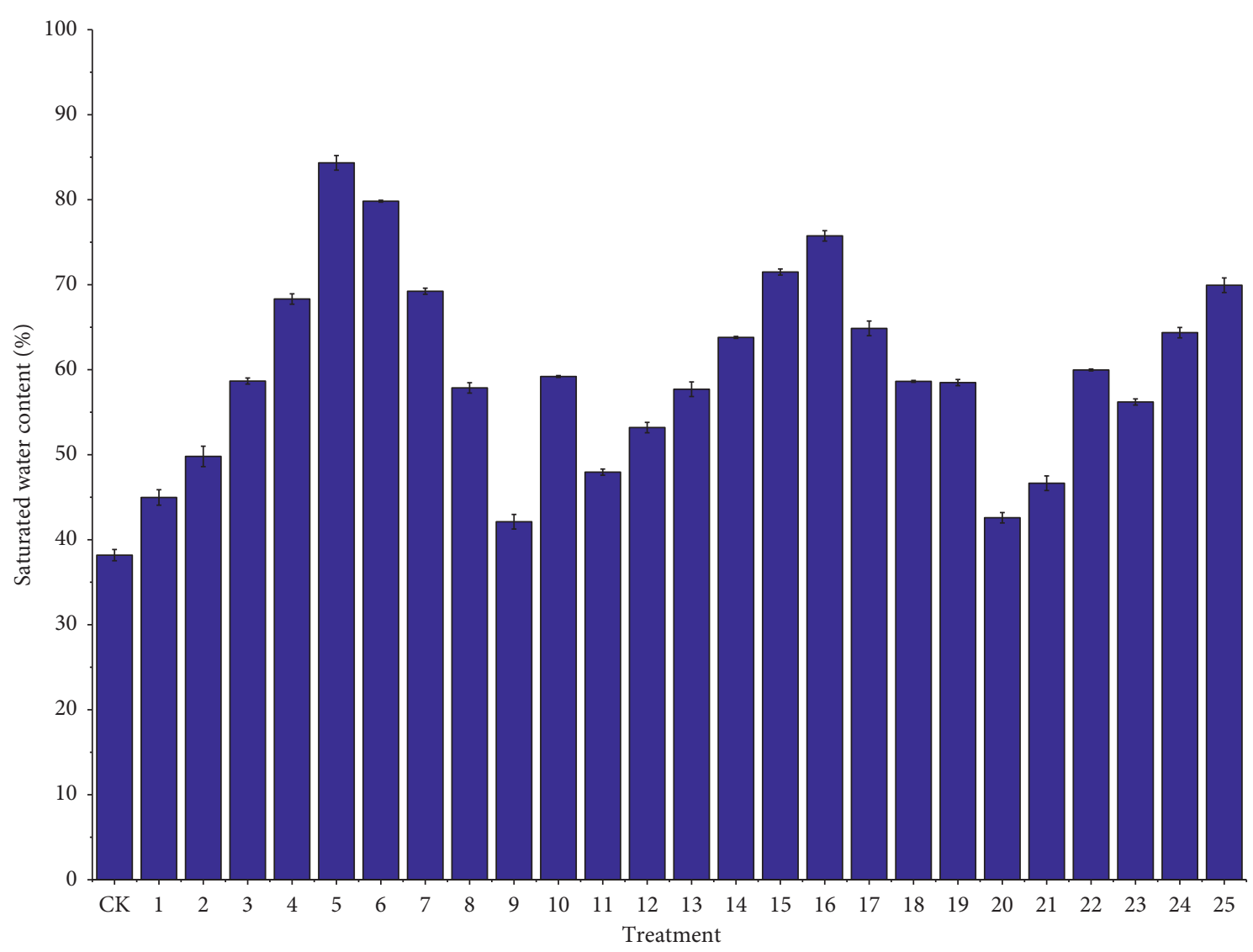

Figure 4: The saturated water capacity of different substrates.

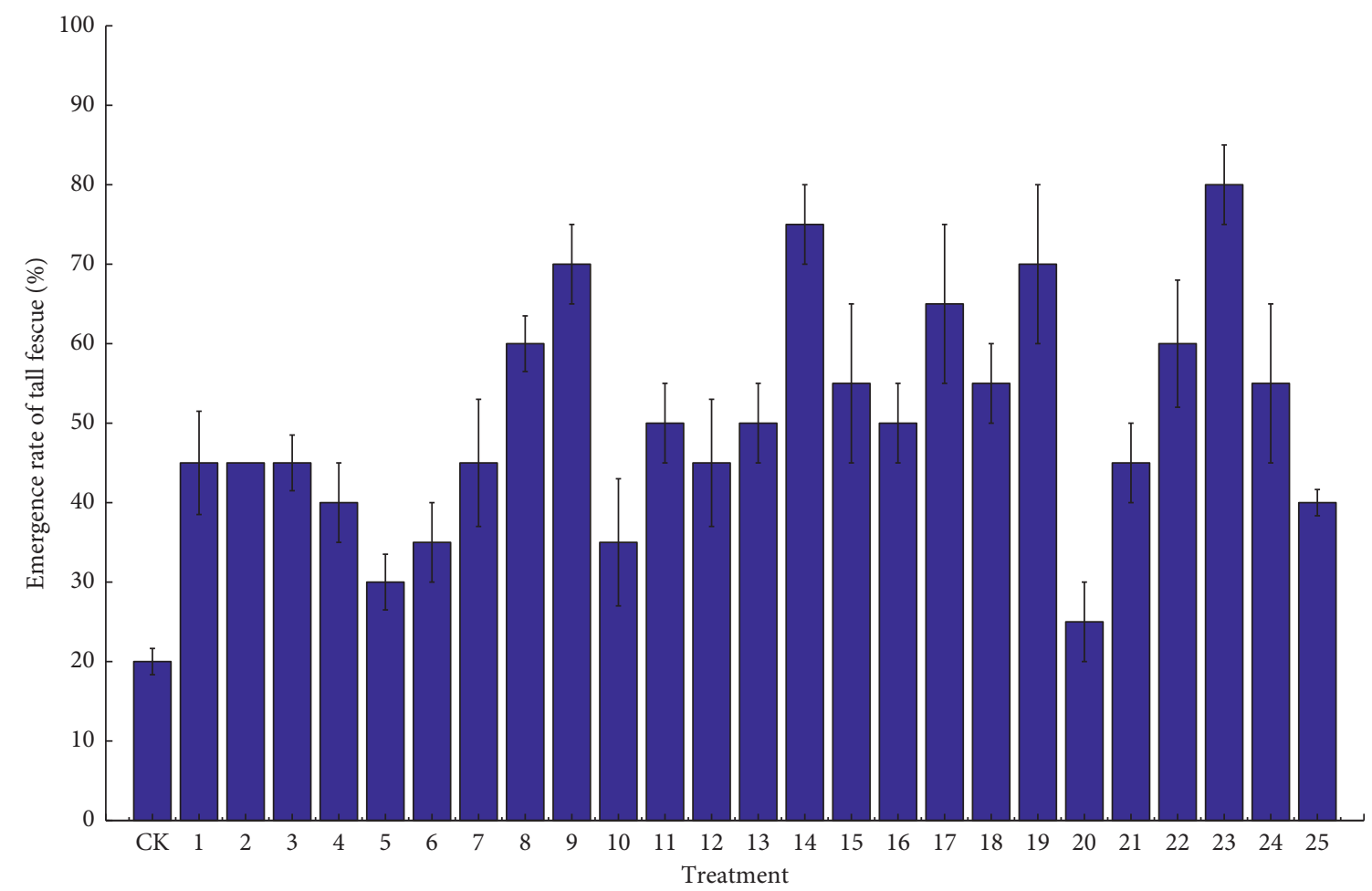

Figure 5: The emergence rate of tall fescue in different substrates. 
TABLE 3: Range analysis of variance for soil organic matter; extractable N, P, and K; bulk density; total porosity; saturated water capacity; and germination rate.

\begin{tabular}{|c|c|c|c|c|c|c|c|c|c|}
\hline Items & Coefficient & $k 1$ & $k 2$ & $k 3$ & $k 4$ & $k 5$ & $R$ & Order of the factor & $\begin{array}{c}\text { Optimal combination } \\
(\mathrm{g} / \mathrm{kg})\end{array}$ \\
\hline \multirow{3}{*}{ Organic C } & PAM & 5.85 & 6.15 & 5.55 & 6.01 & 5.7 & 0.61 & \multirow{3}{*}{ Straw $>$ SAP $>$ PAM } & A2 $(1.0 \mathrm{~g} / \mathrm{kg})$ \\
\hline & Straw & 5.46 & 5.27 & 5.53 & 5.68 & 7.31 & 2.05 & & B5 $(35 \mathrm{~g} / \mathrm{kg})$ \\
\hline & SAP & 5.13 & 5.79 & 5.96 & 6.03 & 6.34 & 1.22 & & C5 $(12 \mathrm{~g} / \mathrm{kg})$ \\
\hline \multirow{3}{*}{ Extractable $\mathrm{N}$} & PAM & 85.31 & 73.53 & 84.94 & 93.08 & 94.98 & 21.45 & \multirow{3}{*}{ Straw $>$ PAM $>$ SAP } & A5 $(2.5 \mathrm{~g} / \mathrm{kg})$ \\
\hline & Straw & 76.89 & 81.76 & 82.03 & 91.84 & 99.32 & 22.43 & & B5 (35 g/kg) \\
\hline & SAP & 79.73 & 94.84 & 86.56 & 84.5 & 86.2 & 15.12 & & $\mathrm{C} 2(3 \mathrm{~g} / \mathrm{kg})$ \\
\hline \multirow{3}{*}{ Extractable $\mathrm{P}$} & PAM & 148.37 & 119.94 & 116.32 & 111.97 & 134.17 & 36.4 & \multirow{3}{*}{ Straw $>$ SAP $>$ PAM } & $\mathrm{A} 1(0.5 \mathrm{~g} / \mathrm{kg})$ \\
\hline & Straw & 133.19 & 140.8 & 164.03 & 105.11 & 87.64 & 76.38 & & B3 $(25 \mathrm{~g} / \mathrm{kg})$ \\
\hline & SAP & 144.77 & 129.74 & 107.68 & 118.18 & 130.4 & 37.08 & & $\mathrm{C} 1(0 \mathrm{~g} / \mathrm{kg})$ \\
\hline \multirow{3}{*}{ Extractable K } & PAM & 591 & 639.33 & 496.53 & 438.91 & 396.09 & 243.24 & \multirow{3}{*}{ Straw $>$ PAM $>$ SAP } & $\mathrm{A} 2(1.0 \mathrm{~g} / \mathrm{kg})$ \\
\hline & Straw & 660.84 & 435.48 & 623.05 & 527.46 & 315.04 & 345.8 & & B1 (15 g/kg) \\
\hline & SAP & 426.78 & 551.52 & 462.29 & 561.59 & 559.69 & 134.81 & & C5 $(12 \mathrm{~g} / \mathrm{kg})$ \\
\hline \multirow{3}{*}{ Bulk density } & PAM & 1.032 & 1.032 & 1.048 & 0.996 & 0.994 & 0.054 & \multirow{3}{*}{$\mathrm{SAP}>\mathrm{PAM}>$ straw } & A5 $(2.5 \mathrm{~g} / \mathrm{kg})$ \\
\hline & Straw & 1.014 & 1.03 & 1.044 & 1.018 & 0.996 & 0.048 & & B5 $(35 \mathrm{~g} / \mathrm{kg})$ \\
\hline & SAP & 1.174 & 1.072 & 1.032 & 0.97 & 0.854 & 0.32 & & C5 $(12 \mathrm{~g} / \mathrm{kg})$ \\
\hline \multirow{3}{*}{ Total porosity } & PAM & 55.83 & 57.336 & 57.626 & 59.482 & 61.444 & 5.614 & \multirow{3}{*}{$\mathrm{SAP}>\mathrm{PAM}>$ straw } & A5 $(2.5 \mathrm{~g} / \mathrm{kg})$ \\
\hline & Straw & 58.46 & 59.432 & 57.918 & 58.712 & 57.196 & 2.236 & & B2 $(20 \mathrm{~g} / \mathrm{kg})$ \\
\hline & SAP & 53.366 & 54.58 & 57.572 & 61.472 & 64.728 & 11.362 & & C5 $(12 \mathrm{~g} / \mathrm{kg})$ \\
\hline \multirow{3}{*}{$\begin{array}{l}\text { Saturated water } \\
\text { capacity }\end{array}$} & PAM & 0.566 & 0.582 & 0.588 & 0.626 & 0.646 & 0.08 & \multirow{3}{*}{$\mathrm{SAP}>\mathrm{PAM}>$ straw } & A5 $(2.5 \mathrm{~g} / \mathrm{kg})$ \\
\hline & Straw & 0.612 & 0.612 & 0.588 & 0.602 & 0.594 & 0.024 & & $\mathrm{~B} 1(20 \mathrm{~g} / \mathrm{kg})$ \\
\hline & SAP & 0.484 & 0.526 & 0.58 & 0.66 & 0.758 & 0.274 & & C5 $(12 \mathrm{~g} / \mathrm{kg})$ \\
\hline \multirow{3}{*}{ Germination rate } & PAM & 12.8 & 10.8 & 8 & 9.6 & 9.6 & 4.8 & \multirow{3}{*}{$\mathrm{PAM}>\mathrm{SAP}>$ straw } & $\mathrm{A} 1(0.5 \mathrm{~g} / \mathrm{kg})$ \\
\hline & Straw & 8.2 & 9.8 & 11 & 10.6 & 11.2 & 3 & & B5 $(35 \mathrm{~g} / \mathrm{kg})$ \\
\hline & SAP & 8 & 11.6 & 11.6 & 11.2 & 8.4 & 3.6 & & $\mathrm{C} 2(3 \mathrm{~g} / \mathrm{kg})$ \\
\hline
\end{tabular}

$R$ is the range; $k_{\mathrm{i}}$ is the average value of the index sum corresponding to the level factor.

TABLE 4: One-way analysis of variance for organic C; available N, P, and K; soil bulk density; total porosity; saturated water capacity; field capacity; and germination rate.

\begin{tabular}{|c|c|c|c|c|c|}
\hline Items & $\begin{array}{c}\text { Classification of } \\
\text { variance }\end{array}$ & $\begin{array}{c}\text { Sum of squares of } \\
\text { deviation from mean }\end{array}$ & Mean square error & $F$ & $p$ \\
\hline \multirow{3}{*}{ Organic C } & PAM & 1.152 & 0.288 & 1.102 & 0.4 \\
\hline & Straw & 13.807 & 3.452 & 13.201 & 0 \\
\hline & SAP & 4.083 & 1.021 & 3.903 & 0.03 \\
\hline \multirow{3}{*}{ Extractable $\mathrm{N}$} & PAM & 1435.685 & 358.921 & 3.339 & 0.047 \\
\hline & Straw & 1637.814 & 409.454 & 3.809 & 0.032 \\
\hline & SAP & 597.03 & 149.258 & 1.388 & 0.296 \\
\hline \multirow{3}{*}{ Extractable $\mathrm{P}$} & PAM & 4470.449 & 1117.612 & 1.204 & 0.359 \\
\hline & Straw & 18121.042 & 4530.261 & 4.881 & 0.014 \\
\hline & SAP & 3910.451 & 977.613 & 1.053 & 0.421 \\
\hline \multirow{3}{*}{ Extractable $\mathrm{K}$} & PAM & 207349.274 & $51,837.318$ & 1.891 & 0.177 \\
\hline & Straw & 396860.139 & $99,215.035$ & 3.62 & 0.037 \\
\hline & SAP & 80137.184 & $20,034.296$ & 0.731 & 0.588 \\
\hline \multirow{3}{*}{ Bulk density } & PAM & 0.012 & 0.003 & 0.891 & 0.499 \\
\hline & Straw & 0.006 & 0.002 & 0.495 & 0.74 \\
\hline & SAP & 0.283 & 0.071 & 21.705 & 0 \\
\hline \multirow{3}{*}{ Total porosity } & PAM & 93.784 & 23.446 & 2.016 & 0.156 \\
\hline & Straw & 14.16 & 3.54 & 0.304 & 0.869 \\
\hline & SAP & 450.42 & 112.605 & 9.683 & 0.001 \\
\hline \multirow{3}{*}{ Saturated water capacity } & PAM & 0.023 & 0.006 & 2.572 & 0.092 \\
\hline & Straw & 0.003 & 0.001 & 0.31 & 0.866 \\
\hline & SAP & 0.246 & 0.061 & 27.418 & 0 \\
\hline \multirow{3}{*}{ Germination rate } & PAM & 63.36 & 15.84 & 6.968 & 0.004 \\
\hline & Straw & 29.76 & 7.44 & 3.273 & 0.049 \\
\hline & SAP & 64.96 & 16.24 & 7.144 & 0.003 \\
\hline
\end{tabular}


and $\mathrm{K}$ ) in dredged soil, which could be due to the straw being decomposed by microorganisms in the dredged soil, a process that can provide nutrients needed by plants, such as soil organic matter and extractable N, P, and K [33]. Excessive straw application, on the other hand, cannot continuously increase the amount of available $\mathrm{P}$ and $\mathrm{K}$ in dredged soil (Figure S1). This is because different types of soil active organic carbon contribute differently to the availability of soil nutrients [34]. Alvarez et al. discovered that, during the decomposition of straw, low-molecularweight organic acids and short-chain fatty acids were released, which were humified with soil organic matter by the action of soil microorganisms, resulting in organic matter in the form of readily oxidizable carbon. This part of the organic matter was shown to be significantly positively correlated with extractable $\mathrm{N}(p<0.01)$ and significantly negatively correlated with extractable $\mathrm{K}(p<0.05)$ [35].

Meanwhile, the findings of this study indicated that soil organic matter was positively correlated to SAP content (Figure S1). SAP application may cause the soil to develop more pores and retain water [36], which improves conditions for straw decomposition and transformation $[37,38]$. Liu et al. conducted a pot experiment to determine the effects of SAP on nutrient uptake and accumulation in Pinus sylvestris seedlings. The results showed that the combined application of SAP and fertilizer increased the amount of $\mathrm{N}$ and $\mathrm{K}$ in the soil by $7.15 \%$ and $10.04 \%$, respectively, as compared to a single fertilizer application [39].

This study established that PAM increased the available $\mathrm{N}$ content in dredged soil, as it was positively correlated with PAM content (Figure S1). This is because available $\mathrm{N}$ is a water-soluble material that may be transported through water flow. The anionic PAM molecule adsorbs cationic particles in the soil, forming larger aggregates that improve soil porosity and water infiltration and soil water retention capacity, thus increasing the retention of available $\mathrm{N}[40,41]$.

5.2. Effects of Different Substrates on Water Retention and Physical Properties. This study established that different substrates' amendments improved the water retention of dredged soil, which is consistent with previous studies on the water retention of substrate materials [8, 20, 42, 43]. The results of this study indicate that SAP had a significant effect on water retention and physical properties in dredged soil. This effect could be explained by the fact that SAP is composed of cross-linked macromolecules with segments of hydrophilic groups that can absorb and retain liquids, and the absorbed water is gradually released into the soil as the soil dries and plant root pressure increases. This is the mechanism that ensures sufficient water supply during vegetation growth $[44,45]$. Bai et al. observed that the volume of SAP varies with the amount of water released during wetting/drying cycles. Therefore, more pores are formed and the bulk density of the soil is reduced, and the larger the amount, the better the effect [36]. According to the findings of this study, the optimal PAM dose for water retention and physical characteristics of dredged soils was $2.5 \mathrm{~g} / \mathrm{kg}$, and the soil bulk density was negatively correlated with PAM content, while soil total porosity and water retention were positively correlated. This is because when PAM molecules come into contact with water molecules, the hydrophobic base may shift inward due to hydrophobic action, resulting in a granular structure that is insoluble in water. Hydrated water is formed by hydrogen bonding between hydrophilic groups and water molecules. Meanwhile, PAM molecular chains interact with soil particles to form a three-dimensional bridge structure, which allows larger flocs and improves soil structure [46].

5.3. Effects of Different Substrates on the Germination Rate of Tall Fescue in Dredged Soil. In this study, the three substrates' amendments significantly enhanced the germination rate of tall fescue in dredged soil. It was discovered that a high PAM content may significantly inhibit the germination of tall fescue, and the optimal PAM dose was $0.5 \mathrm{~g} / \mathrm{kg}$. This is consistent with previous studies [47]. In a laboratory pot experiment, Zheng et al. examined the impact of $0,0.125$, 0.250 , and $0.5 \mathrm{~g} / \mathrm{kg}$ PAM on seed germination and seedling growth of Neyraudia reynaudiana. Their findings demonstrated that PAM can promote reed seed germination, shorten the germination time, and increase the germination rate. However, too much or too little causes the germination rate of Neyraudia reynaudiana seeds to decrease. This may be because excessively applied PAM competes with the seeds for water, affecting seed germination [48]. Taylor and Halfacre attributed growth depression in polymer-treated Ligustrum to the possibility that an accumulation of fertilizer salts in the gel caused toxicity [49]. Excess PAM has been demonstrated in previous research to affect the germination of vegetation. The effect of PAM on vegetation growth, on the other hand, is a complex topic. Further research on the mechanism of PAM on vegetation growth and development is required.

Furthermore, the findings of this study revealed straw content was positively correlated with tall fescue germination in dredged soil. This was consistent with the findings of previous investigations [50]. Straw decomposes to generate a significant quantity of inorganic elements, humus, and organic matter, which offer nutrients for the development of tall fescue seeds, as well as promote the activity of microorganisms and seed germination [51, 52].

The findings of this study showed that SAP significantly affected the emergence rate of tall fescue. However, increasing the amount of SAP in dredged soil did not improve the emergence rate of tall fescue (Figure S1), and the optimal SAP dose was $3 \mathrm{~g} / \mathrm{kg}$. This may be due to high SAP content causing poor bulk density, which in turn causes seed degradation.

\section{Conclusions}

This study has established an effective strategy for improving dredged soil via the use of SAP, PAM, and straw. The effects of different amendments on dredged soil differ. SAP has been shown to significantly decrease the bulk density of dredged soil while increasing its water retention capacity and 
overall porosity $(p<0.05)$. However, increasing the amount of SAP in dredged soil had no consistent effect on tall fescue emergence rate, and the optimal SAP dose was $3 \mathrm{~g} / \mathrm{kg}$. PAM may enhance the structural properties of dredged soil and increase its water holding capacity and available $\mathrm{N}$ retention. However, an excess of PAM content may significantly inhibit tall fescue germination, and the optimal dose of PAM for tall fescue germination was $0.5 \mathrm{~g} / \mathrm{kg}$. Straw decomposition enhances the nutritional content of dredging soil, supplies nutrients for tall fescue growth, and improves germination rate.

\section{Data Availability}

The data used to support the findings of this study are included within the article.

\section{Conflicts of Interest}

The authors declare no conflicts of interest.

\section{Supplementary Materials}

Figure S1: the trend curve for each factor. () (Supplementary Materials)

\section{References}

[1] V. Dubois, R. Zentar, N.-E. Abriak, and P. Grégoire, "Fine sediments as a granular source for civil engineering," European Journal of Environmental and Civil Engineering, vol. 15, no. 2, pp. 137-166, 2011.

[2] X. Bian, L. Zeng, Y. Deng, and X Li, "The role of superabsorbent polymer on strength and microstructure development in cemented dredged clay with high water content," Polymers, vol. 10, no. 10, 2018.

[3] M. C. Casado-Martínez, J. L. Buceta, M. J. Belzunce, and T. A. DelValls, "Using sediment quality guidelines for dredged material management in commercial ports from Spain," Environment International, vol. 32, no. 3, pp. 388-396, 2006.

[4] J. Stronkhorst, F. Ariese, B. Van Hattum et al., "Environmental impact and recovery at two dumping sites for dredged material in the North Sea," Environmental Pollution, vol. 124, no. 1, pp. 17-31, 2003.

[5] N. Yoobanpot, P. Jamsawang, P. Simarat, P. Jongpradist, and S. Likitlersuang, "Sustainable reuse of dredged sediments as pavement materials by cement and fly ash stabilization," Journal of Soils and Sediments, vol. 20, 2020.

[6] H. DU and S. D. Pang, "Value-added utilization of marine clay as cement replacement for sustainable concrete production," Journal of Cleaner Production, vol. 198, pp. 867-873, 2018.

[7] L.-x. Yang, S.-c. Li, H.-l. Sun, F.-f. Ye, W. Liu, and S. Luo, "Polyacrylamide molecular formulation effects on erosion control of disturbed soil on steep rocky slopes," Canadian Journal of Soil Science, vol. 91, no. 6, pp. 917-924, 2011.

[8] H. Yang, S. Li, H. Sun, W. Wang, and F. Zhao, "Effects of substrate material on plant growth and nutrient loss," Polish Journal of Environmental Studies, vol. 27, no. 6, pp. 28212832, 2018.

[9] C. Li, Z. Jia, Y. Yuan et al., "Effects of mineral-solubilizing microbial strains on the mechanical responses of roots and root-reinforced soil in external-soil spray seeding substrate," The Science of the Total Environment, vol. 723, 2020.
[10] M. D. Bishop, S. Kim, A. M. Palomino, and J.-S. Lee, "Deformation of "tunable" clay-polymer composites," Applied Clay Science, vol. 101, pp. 265-271, 2014.

[11] S. Kim and A. M. Palomino, "Factors influencing the synthesis of tunable clay-polymer nanocomposites using bentonite and polyacrylamide," Applied Clay Science, vol. 51, no. 4, pp. 491-498, 2011.

[12] S. Kim and A. M. Palomino, "Polyacrylamide-treated kaolin: a fabric study," Applied Clay Science, vol. 45, no. 4, pp. 270-279, 2009.

[13] A. Inbar, M. Ben-Hur, M. Sternberg, and M. Lado, "Using polyacrylamide to mitigate post-fire soil erosion," Geoderma, vol. 239-240, pp. 107-114, 2015.

[14] J. Zhou, X. Liang, S. Shan et al., "Nutrient retention by different substrates from an improved low impact development system," Journal of Environmental Management, vol. 238, pp. 331-340, 2019.

[15] H. Y. Lei, Y. G. Xu, X. Li, and G. Zeng, "Effects of polyacrylamide on the consolidation behavior of dredged clay," Journal of Materials in Civil Engineering, vol. 30, no. 3, 2018.

[16] H. Soltani-Jigheh, M. Bagheri, and A. R. Amani-Ghadim, "Use of hydrophilic polymeric stabilizer to improve strength and durability of fine-grained soils," Cold Regions Science and Technology, vol. 157, pp. 187-195, 2019.

[17] A. Soltani, A. Deng, A. Taheri, and M. Mirzababaei, "Rubber powder-polymer combined stabilization of South Australian expansive soils," Geosynthetics International, vol. 25, no. 3, pp. 304-321, 2018.

[18] K.-t. Lau, P.-y. Hung, M.-H. Zhu, and D. Hui, "Properties of natural fibre composites for structural engineering applications," Composites Part B: Engineering, vol. 136, pp. 222-233, 2018.

[19] W. Xie, Q. Chen, L. Wu, H. Yang, J. Xu, and Y. Zhang, "Coastal saline soil aggregate formation and salt distribution are affected by straw and nitrogen application: a 4-year field study," Soil and Tillage Research, vol. 198, 2020.

[20] Y. Qiu, W. Lv, X. Wang, Z. Xie, and Y. Wang, "Long-term effects of gravel mulching and straw mulching on soil physicochemical properties and bacterial and fungal community composition in the Loess Plateau of China," European Journal of Soil Biology, vol. 98, 2020.

[21] Y.-N. Chen, C.-H. Zhang, Y.-J. Liang et al., "Corn straw composting in the field and in situ fertilizer effect," Ying yong sheng tai xue bao = The journal of applied ecology, vol. 25, no. 12, pp. 3507-3513, 2014.

[22] J. G. Shrikhande, "The production of mucus during the decomposition of plant materials1," Biochemical Journal, vol. 27, no. 5, pp. 1551-1562, 1933.

[23] M. R. Islam, Y. Hu, S. Mao, J. Mao, A. E. Eneji, and X. Xue, "Effectiveness of a water-saving super-absorbent polymer in soil water conservation for corn (Zea mays L.) based on ecophysiological parameters," Journal of the Science of Food and Agriculture, vol. 91, no. 11, pp. 1998-2005, 2011.

[24] A. R. Sepaskhah and A. R. Bazrafshan-Jahromi, "Controlling runoff and erosion in sloping land with polyacrylamide under a rainfall simulator," Biosystems Engineering, vol. 93, no. 4, pp. 469-474, 2006.

[25] R. A. I. Azzam, "Polymeric conditioner gels for desert soils," Communications in Soil Science and Plant Analysis, vol. 14, 1983.

[26] S. Elamir and A. M. Helalia, "Effects of acryhope and aquastore polymers on water regime and porosity in sandy soil," Proceedings of the Agu Fall Meeting, F, vol. 6, no. 1-2, pp. 19-25, 1991. 
[27] K. Watanabe, S. Saensupo, Y. Na-Iam, P. Klomsa-ard, and K. Sriroth, "Effects of superabsorbent polymer on soil water content and sugarcane germination and early growth in sandy soil conditions," Sugar Tech, vol. 21, no. 3, pp. 444-450, 2019.

[28] W. Yang, P. Li, S. Guo, R. Song, and J. Yu, "Co-application of soil superabsorbent polymer and foliar fulvic acid to increase tolerance to water deficit maize: photosynthesis, water parameters, and proline," Chilean Journal of Agricultural Research, vol. 79, no. 3, pp. 435-446, 2019.

[29] T. Du, D. Wang, Z. Z. Zhang, X. Zhao, Z. Zhang, and R. Zhang, "Effect of the water-retaining property of coal gangue planting substrate on the growth of Lofium perenne," Science of Soil and Water Conservation, vol. 17, no. 4, pp. 75-84, 2019.

[30] D. W. Nelson and L. E. Sommers, "Total carbon, organic carbon and organic matter," in Methods of Soil Analysis Part 2: Chemical and Microbial Properties, American Society of Agronomy, Madison, MI, USA, 1982.

[31] S. R. Olsen, "Estimation of available phosphorus in soils by extraction with sodium bicarbonate," Bibli, vol. 939, pp. 18-19, 1954.

[32] M. L. Jackson, "Soil chemical analysis," Soil ence, vol. 85, no. 22, p. 288, 1973.

[33] H. Zhu, J. Wu, D. Huang, and Qihong Zhu, Shoulong Liu, Yirong Su, Wenxue Wei, J. Keith Syers \& Yong Li, "Improving fertility and productivity of a highly-weathered upland soil in subtropical China by incorporating rice straw," Plant and Soil, vol. 331, no. s1-2, pp. 427-437, 2010.

[34] S. C. Yu, X.-y. Zhang, X. Liu, and C.-s. Gao, "Effect of soil organic matter on soil fertility and crop productivity," System sciences and comprehensive studies in agriculture, vol. 24, no. 3, pp. 357-362, 2008.

[35] R. Alvarez, C. R. Alvarez, and H. S. Steinbach, "Association between soil organic matter and wheat yield in Humid Pampa of Argentina," Communications in Soil ence \& Plant Analysis, vol. 33, no. 5-6, pp. 749-757, 2002.

[36] W. Bai, H. Zhang, B. Liu, Y. Wu, and J. Song, "Effects of superabsorbent polymers on the physical and chemical properties of soil following different wetting and drying cycles," Soil Use \& Management, vol. 26, no. 3, pp. 253-260, 2010.

[37] T. Mueller, L. S. Jensen, N. E. Nielsen, and J. Magid, “Turnover of carbon and nitrogen in a sandy loam soil following incorporation of chopped maize plants, barley straw and blue grass in the field," Soil Biology and Biochemistry, vol. 30, no. 5, pp. 561-571, 1998.

[38] L. Renkuan, Y. Peiling, and R. Shumei, "Review on super absorbent polymer application for improving fertilizer efficiency and controlling agricultural non-point source pollutions," Transactions of the Chinese Society of Agricultural Engineering, vol. 28, no. 17, pp. 1-10, 2012.

[39] F. Liu, H. Ma, S. Xing, Z. Du, B. Ma, and D. Jing, "Effects of super-absorbent polymer on dry matter accumulation and nutrient uptake of Pinus pinaster container seedlings," Journal of Forest Research, vol. 18, no. 3, pp. 220-227, 2013.

[40] S. M. Aly and J. Letey, "Polymer and water quality effects on flocculation of montmorillonite," Soil Science Society of America Journal, vol. 52, no. 5, pp. 1453-1458, 1988.

[41] B. K. G. Theng, "Clay-polymer interactions: summary and perspectives," Clays and Clay Minerals, vol. 30, no. 1, pp. 1-10, 1982.

[42] R. Liao, W. Wu, S. Ren, and P. Yang, "Effects of superabsorbent polymers on the hydraulic parameters and water retention properties of soil," Journal of Nanomaterials, vol. 2016, Article ID 5403976, 11 pages, 2016.
[43] L. Githinji, "Effect of biochar application rate on soil physical and hydraulic properties of a sandy loam," Archives of Agronomy and Soil Science, vol. 60, no. 4, pp. 457-470, 2014.

[44] D. M. Devine and C. L. Higginbotham, "Synthesis and characterisation of chemically crosslinked N-vinyl pyrrolidinone (NVP) based hydrogels," European Polymer Journal, vol. 41, no. 6, pp. 1272-1279, 2005.

[45] E. Fernández, D. López, E. López-Cabarcos, and C. Mijangos, "Viscoelastic and swelling properties of glucose oxidase loaded polyacrylamide hydrogels and the evaluation of their properties as glucose sensors," Polymer, vol. 46, no. 7, pp. 2211-2217, 2005.

[46] B. K. Halder, A. M. Palomino, and J. Hicks, "Influence of polyacrylamide conformation on fabric of "tunable" kaolinpolymer composite," Canadian Geotechnical Journal, vol. 55, no. 9, pp. 1295-1312, 2018.

[47] X. H. Li and W. G. Li, "Effects of polyacrylamide on gemination and growth of several plant seeds," Chinese Journal of Eco-Agriculture, vol. 4, pp. 77-79, 2002.

[48] H. X. Zheng, X. Huang, L. P. Cai et al., "Effects of soil particle composition and adhesives on seed germination and seedling growth of Neyraudia reynaudiana," Acta Prataculturae Sinica, vol. 2, pp. 92-102, 2020.

[49] K. C. Taylor and R. G. Halfacre, "The effect of hydrophilic polymer on media water retention and nutrient availability to Ligustrum lucidum," Hortence, vol. 21, no. 5, pp. 1159-1161, 1986.

[50] H. Blanco-Canqui, R. Lal, W. M. Post, and L. B. Owens, "Changes in long-term No-till corn growth and yield under different rates of stover mulch," Agronomy Journal, vol. 98, no. 4, Article ID 1128, 2006.

[51] S. P. Swanson and W. W. Wilhelm, "Planting date and residue rate effects on growth, partitioning, and yield of corn," Agronomy Journal, vol. 88, no. 2, pp. 205-210, 1996.

[52] J. F. Power, W. W. Wilhelm, and J. W. Doran, "Crop residue effects on soil environment and dryland maize and soya bean production," Soil and Tillage Research, vol. 8, pp. 101-111, 1986. 